\title{
WYKOPALISKA W HACOR
}

Każde wykopaliska prowadzone na terenach wspomnianych przez Biblię, przynoszą wiele często nawet nieoczekiwanych pozytywnych rezultatów zarówno dla samych archeologów jak również i dla biblistów. Zwykle dla tych ostatnich są one potwierdzeniem prawdziwości danych biblijnych. Tak się też ma i sprawa $z$ wykopaliskami prowadzonymi na terenie dawnego miasta Hacor.

Wykopaliska te $\mathrm{z}$ ramienia hebrajskiego Uniwersytetu w Jerozolimie prowadziła w ubiegłym roku przez trzy miesiące (od sierpnia do października 1955) grupa archeologów pod kierunkiem Yigaela Jadina, syna znanego prof. Sukiennika. W ekspedycji brało udział 30 wykształoonych specjalistów archeologów oraz 120 pracowników technicznych. Eikspedycja postawiła sobie trzy zasadnicze zadania do osiągnięcia: 1. Wykazać jaki jest charakter słynnego $\mathrm{z}$ dokumentów biblijnych i pozabiblijnych Hacoru. Czy był on tylko zwykłym obozem wojskowym, panującym nad kilkoma rozgałęzieniami słynnej podówczas „Via Maris", wiodącej z Egiptu do Mezopotamii, czy może była to tylko jedna $z$ większych zagród, albo też było to $w$ całym tego słowa znaczeniu wielkie o wysokiej kulturze materialnej, prawdziwe miasto. Jeśli Hacor było miastem, to $\mathrm{w}$ takim razie kto i kiedy zadał mu ostateczny cios i zamienił je w ruinę? 2. Sprawdzić, czy dane biblijne o zdobyciu Fiacoru i o jego świetności pod panowaniem Izraelitów mają swoje pokrycie w rzeczywistości, oraz 3. wykazać na podstawie tych wvkopalisk ${ }^{1}$ ) jedynych prowadzonych dotychczas na pólnoc od jeziora Tyberiadzkiego, jak wysoką była w owych czasach kultura materialna całej północnej Palestyny. Czy ekspedycja osiągnęla cele, jakie sobie wytknęła?

Prace badawcze zaczęto prowadzić na szerokiej równinie, położonej ok. $14 \mathrm{~km}$ na północ od Morza Galilejskiego oraz ok. $8 \mathrm{~km}$ na południowy zachód od biblijnego jeziora Merom. Rozkopano własciwe wzgórze na przestrzeni ok. $600 \mathrm{~m}$ długości, $200 \mathrm{~m}$ szerokości, oraz ok. $40 \mathrm{~m}$ wysokości, a więc teren prawie dwa razy większy aniżeli Megiddo. Oprócz tego przekopano dokładnie płaskowyż ciągnący się na północ od owego wzgórza wielkości 1000 na 700 m otoczony z trzech stron głębokimi jarami a z czwartej walem z ubitej ziemi dochodzącym do $15 \mathrm{~m}$ wysokości. Już sam ten wstępny opis wskazuje na mocno ufortyfikowany teren, na którym zdaniem Prof. J. Garstanga w razie potrzeby mogło się pomieścić ok. 30.000 ludzi z odpowiednią ilością wozów i koni.

Rezultaty badań można (sprowadzić do następujących danych: 1). Wykopaliska prowadzono na terenie samego wzgórza po jego południowo-wschodniej stronie, na t. zw. ,przestrzeni A“ (patrz załączony plan wykopalisk). Odkopanie 4 warstw ziemi, pozwoliło na od-

1) Prace wykopaliskowe prowadzone w latach 1928 na mała skalę przez J. Garstanga nie wchodzą tu w rachubę 
krycie i zidentyfikowanie samego miasta 4 razy palonego i znowu odbudiwywanego. Pierwsza warstwa od góry odkopana ukazała szczątki miasta $z$ końca VIII w. Było to już wtedy niewielkie osiedle. Pod drugą warstwą znaleziono miasto zupełnie spalone. Pewne charakterystyczne cechy, jak zapadnięte dachy domów, naczynia bazaltowe i gliniane porozrzucane $\mathrm{w}$ nieładzie, brak porządku w domach, pozwalają przy-

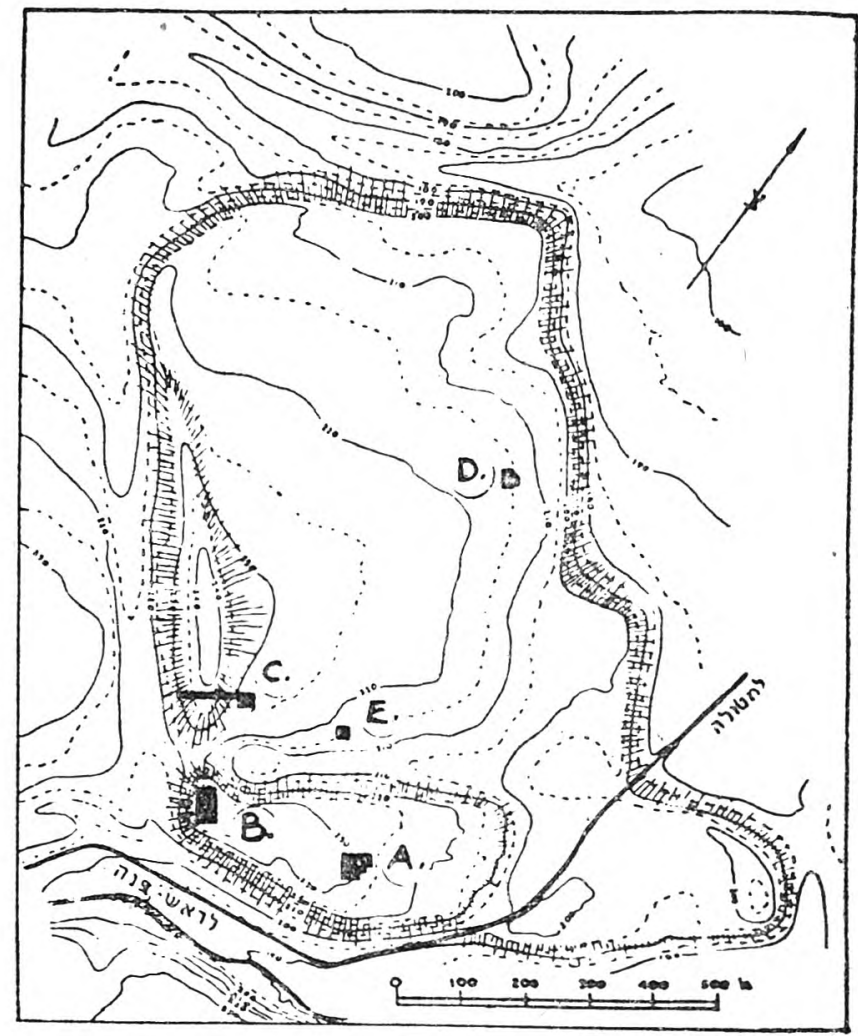

puszczać, że miasto przeżyło jakiś gwałtowny najazd wroga, który zamienił je w ruinę. Był to najazd Teglatfalassara III, w 732 r. Pod trzecią warstwą znaleziono wiele naczyń z IX i VIII w., wskazujące na pewną świetność i dostatek miasta. Czwarta warstwa ukazała ruiny miasta z czasów panowania króla izraelskiego Achaba, a więc mniej więcej druga połowa IX w. Najważniejszą budowlą z tego okresu był odkopany wielki budynek o dwóch rzędach jednolitych kolumn, każda po 9 filarów. Filary miały wysokość $2 \mathrm{~m}$. Był to jak1ś budynek użyteczności publicznej, a nie jak chciał J. Garstang resztki stajni Salomona. Najważniejsze jest to, że pod tymi 4 warstwamı dopatrzono się 
jeszcze 3 warstw miast jeszcze starszych, bo pochodzących $z$ wieku żelaznego. W wyżej przelkopanych 4 warstwach odnaleziono, szereg naczyń i różnych przedmiotów, z których najważniejsze są: kościana rączka berła pokryta eiekawymi oryginalnymi rzeźbami, oraz postać o 4 slkrzydłach w stylu fenickim, dzierżąca w ręku drzewo żywota.

2. Wykopaliska prowadzone po zachodniej stronie wzgórza (odcinek B) w samym centrum miasta naprowadziły archeologów na ślady wielkich i licznych fortyfikacji. Odkryto kilka fortów budowanych jedne nad drugimi. Najmłodsze forty pochodzą z okresu heleńskiego, najstarsze dotychczas odkopane (jeszcze wszystkich nie odkryto) prawdopodobnic z IX w. Najciekawszą jest cytadela zbudowana na przełomie VIII i VII w. w kształcie kwadratu $\mathrm{z}$ dziedzińcem w środku. Otaczały ją małe pomieszczenia mieszkalne. Przẹbudowywana kilka razy $w$ ostatnim swoim wydaniu służyła prawdopodobnie za garnizon dla małego oddziału kawalerii, jak można wnioskować z licznych żłobów przylegających do owej budowli. Z okresu panowania izraelskiego nad Hacorem, odkryto jeszcze na tym samym terenie część wielkiego muru izraelskiego i odosobnioną, podzieloną na dwie czẹści strażniczą wieżę.

3. Najważniejszych wykopalisk dokonano na prostukątnym płaskowzgórzu, na południowo-zachodnim jego odcinku (t. zw. odcinek ,C“). Wykopaliska przyniosły rewelacyjne wyniki: przede wszystkim odkryto szczątki wspaniale zbudowanego miasta, przechodzacego wszelkie oczekiwania. Domy bogate, posiadajace dobrze rozbudowany system kenalizacyjny, podłogi domów ozdobione ceramiką, wewnątrz mieszkań wiele cennych artystycznych przedmiotów, pochodzacych z XIII w. Oprócz tego odkryto dwie maie świątynie kanaanejskie, jedna nad cruga pochodzace z XV w. Narazie oczyszczono tylko środkową czéść świątyń, reszta terenu zajmowanego przez nie czeka na prace w nastepnym roku. Ale i to co odkryto jest bardzo interesujące. W części tej środkowej świątyni znaleziono bazaltową rzeźbę mężczyzny. prawdopodobnie jakiegoś boga siedzącego na tronie, trzymajacego w rẹu czarę. W około rzeźby na lewo znajdował się rząd zaokraglonych u góry słupów kamiennych, z których środkowy posiadal ciekawy rysunek-rzeźbę, przedstawiającą dwie ręce wzniesione $\mathrm{w}$ modlitewnym geście do góry pod emblematem boga-półksiężyca z tarczą słoneczną w środku. Z boku owych słupów kamiennych odkryto na bazaltowym kamieniu rysunek-płaskorzeźbę lwa leżącego na tylnych łapach z podniesioną glową i przednimi łapami. Liczne naczynia 1 rzeźby odnalezione w tych świątyniach, pochodzą z końca XIV i początku XIII w. Z.daniem poważnych archeologó ${ }^{1}{ }^{1}$ ) mamy tu do czynienia $\mathrm{z}$ ciekawymi zébytkami i wpływami kultury hittyckiej, która jednak w szczegółach i w wykonaniu nosi charakter kanaanejski.

1) Por. Jigael, Excavations at Hazor, art. w The Bib. Arch. 1956, 's. $2-11$. 
4. Następne wykopaliska prowadzone $\mathrm{z}$ drugiej strory prostokątnego

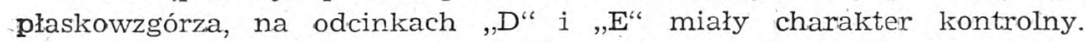
Celem ich było potwrierdzenie danych wykopaliskowych z odcinków A, B i C. Archeolodzy osiągnęli cel, jaki sobie założyli. Wykopane przedmioty nosza te same cechy co i przedmioty znalezione $w$ pozostałych częściach rozkopanego terenu. Stwierdzono, że odkopane budowle pochodzą z XIII w. i zostały wzniesione na ruinach dawnego miasta, które początkami swoimi sięga epoki Hyksosów. Na przestrzeni rozkopanej odkryto liczne cysterny wodne, z których niejedne sięgały $9 \mathrm{~m}$ głębokości. Z wydobytych licznych przedmiotów i bogatej ceramiki, najbardziej ciekawe są małe fragmenty dzbana, z napisanymi na nich dwoma literami: „LT“, z alfabetu protosynaickiego. (Alfabet z którego rozwinęło się stare pismo hebrajskie).

Z powyższych wykopalisk można wyciągnąc następujące wnioski: 1. Na przekopanym terenie znajdowało się rzeczywiście przed laty bogate i wielkie miasto Hacor, które w okresie późnego bronzu (XV w.) stało u szczytu swej potęgi i było jednym z największych miast w Kanaanie. Zamieszkiwało je ok. 40.000 ludności. Zatem prawdziwą jest wzmianka Ks. Jozuego o tym mieście: „Hacor bowiem przed tem było stolicą wszystkich owych królestw" (11, 10), t. j. małych księstw kanaanejskich zjednoczonych w jedno państwo, pod władzą króla z Hacor.

2. Hacor zostało podbite i zburzone przez Jozuego i od tego czasu ulegało wpływom Izraelitów. Wykopaliska potwierdzają ogólnie dziś przyjętą datę wyjścia Izraelitów z Egiptu (połowa XIII) połączoną z najazdem Jozuego na Hacor, (Joz. 11, 10-13), przeciwko nielicznym zdaniom tych archeologów z J. Garstang'iem na czele, którzy tę date przesuwają na wiek XV. Koniec potęgi wielkiego Hacoru zbiega się z okresem podboju tego kraju przez Jozuego. Odnalezione liczne przedmioty, noszące na sobie ślady ceramiki myceńskiej pozwalają nam postawić twierdzenie, że wejście Jozuego do Kanaanu by.ło napewno ok. 1200 r.

3. Wykopaliska powyżej omawiane potwierdzają w całej swej rozciągłości dane o Hacorze, jakie posiadamy w dokumentach biblijnych i pozabiblijnych. Biblia wspomina o Hacorze, najwcześniej u Joz. 11, 10-13, potem Sędz. 4, 2. 24 wyznacza początek końcowej fazy podboju ludów kanaanejskich, w III Król. 9, 15 mówi o odbudowaniu Hacor przez Salomona, zaś w IV Król. 15, 29 o podboju tego miasta przez Teglatfalassara w r. 732. Ostatnia wzmianka historyczna o tym mieście znajduje się w I Mach. 11, 6, gdzie czytamy, że Jonatan walczył przeciw Demetriuszowi na równinie Hacor. Był to rok 147 przed Chr. Z dokumentów pozabiblijnych o Hacorze wspominają: Po raz pierwszy egipskie teksty w XIX w., które wymieniają zewnętrznych nieprzyjaciół państwa egipskiego, między innymi także i miasto Hacor. Teksty pochodzące $\mathrm{z}$ odkopanego miasta Mari (nad środkowym Eufratem) z XVII w. wspominaja o posłach wysłanych z Mezopotamii do Hacor. Wskazywałoby to na to, że Hacor już wtedy było miastem, z którym 
wszyscy się liczyli. Faraonowie egipscy Tutmosis III i Amenofis II wymieniają Hacor wśród miast podbitych. Najciekawsze są wzmianki - omawianym przez nas mieście w korespondencji królów egipskich z Tell-el-Amarna. Mamy tam aż cztery listy mówiące o Hacorze i o intrygach poszczególnych królów kananejskich przeciw Egiptowi. Jest to wiek XIV.

Wszystkie wyżej wspomniane dane znalazły całkowite swoje pokrycie w zeszłorocznych wykopaliskach prowadzonych na terenie omawianego przez nas miasta. Są one jednak niezupełne, ponieważ prace nie zostały jeszcze ukończone. Czekamy jednak na rezultaty badań obecnego sezonu, które odkryją nam historię Hacoru $\mathrm{z}$ okresu ođ XV do XX w. przed Chr.

Kraków

Ks. STANISŁAW GRZYBEK 